> Tips om medisinsk litteratur, andre bøker, filmer og elektroniske medier

som bør anmeldes, sendes tidsskriftet@legeforeningen.no

\section{Kort, godt og enkelt - om ledelse av sykehus}

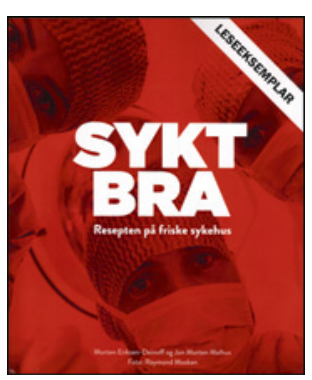

Morten Eriksen-Deinoff, Jon Morten Melhus Sykt bra

Resepten på friske sykehus. 214 s, ill. Oslo:

Melhus Communication, 2013. Pris NOK 349 ISBN 978-82-93130-10-9

Forfatterne er to siviløkonomer med bakgrunn i rådgivnings- og konsulentvirksomhet overfor virksomhetsledere i privat og offentlig sektor. Målgruppen er helseledere på alle nivåer - med sin relativt kortfattede gjennomgang av allmenne prinsipper for ledelse. Søkelyset er rettet mot suksessfaktorer for ledelse og målstyring, og forfatterne understreker behovet for å skille tydelig mellom kunsten å lede medarbeidere og jobben med å administrere en virksomhet.

Dette er ikke en lærebok i ledelse, men en serie intervjuer med til dels profilerte norske sykehusledere, kombinert med oppsummeringer av nokså grunnleggende prinsipper for ledelse. Layouten er tiltalende og illustrasjonene fine. Selv om en av forfatterne omtaler seg selv som «blant de fremste rådgivere i Norge når det gjelder betydningen av begeistring og begeistringsledelse» handler boken heldigvis ikke om begeistring, men om systematisering av alminnelig kunnskap om hvordan ledelse bør utøves. Det er en kortfattet litteraturliste bakerst, men påstander og anbefalinger er i hovedsak ikke belagt med litteraturhenvisninger.

Til sammen ni intervjuer danner et forklarende bakteppe for forfatternes «resept på friske sykehus» og «seks kriterier for å skape bedre sykehus». Det er interessant å lese hvordan de intervjuede, som er personer både med og uten helsefaglig bakgrunn, beskriver sine strategier, tanker og visjoner om god ledelse, selv om noe er preget av allmennkunnskap og alminnelig sunn fornuft på grensen til det banale. Men, som Winston Churchill så viselig formulerte det: «Common sense is after all not that common.»

Lesere som står i krevende lederroller i krysspresset mellom kvalitet, aktivitet og økonomi innenfor dagens rammebetingelser for sykehusdrift, vil nok tenke at boken anviser i overkant enkle løsninger, og at forfatterne går langt i å fremstille de fleste utfordringer som overkommelige, eller til og med nokså enkle å håndtere bare man leder sine medarbeidere tilstrekkelig godt.

Når det er sagt, kan jeg likevel anbefale boken for både ferske og erfarne ledere. Den er rett og slett hyggelig å lese, og minner leseren om betydningen av relasjonsbygging og det å se sine medarbeidere, og slik sørge for at de blir enda bedre. Det enkle er ofte det beste, om enn ikke alltid hele løsningen.

Jan Emil Kristoffersen

Akershus universitetssykehus

\section{Tidsskriftets ansikt}

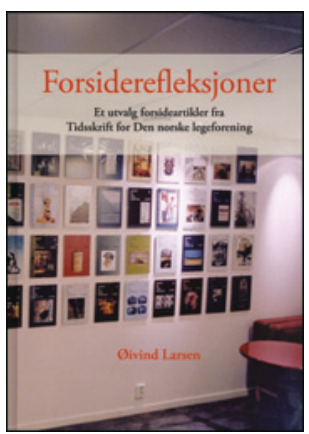

Øivind Larsen

Forsiderefleksjoner

Et utvalg forsideartikler fra Tidsskrift

for Den norske legeforening. 200 s, ill.

Eget forlag, 2013. Pris NOK 290

ISBN 978-82-999082-1-4

Professor emeritus i medisinhistorie, fotograf og kulturskribent, Øivind Larsen, hadde en avtale med Tidsskriftet i perioden 1984 til 2003 hvor han laget forsidebilder med en kommenterende tekst. Han har nå samlet 57 av disse forsidene i en egen bok. Hver av dem er ledsaget av den teksten som var å finne inne i angjeldende nummer. I alt laget Øivind Larsen 537 forsider. Fotografiene var $i$ det alt vesentlige hans egne.

Vel halvparten av de korte artiklene i dette utvalget omhandler medisinhistorie, kunsthistorie eller mer generell historie. Nesten like mange er rene skjønnlitterære tekster og noen få kommentarer til aktuell medisin. For mange av oss vil dette være et nostalgisk gjensyn med Tidsskriftet slik det skulle være etter perioden med den traurige forsiden med innholdsfortegnelsen i en innrammet boks. Slik vil nok dette være mest til glede for Legeforeningens medlemmer og særlig de som har levd noen år. Men tekstene har en allmenngyldighet som er egnet til å begeistre flere enn legeprofesjonen. Bildene er fortsatt interessante, og kommentarene har ikke surnet. De kan leses i dag med like stort utbytte som da de ble trykket. Med fare for å bli panegyrisk vil jeg hevde at mange av artiklene er rene litterære perler.

Boken er gitt ut på eget forlag med støtte fra Det norske medicinske Selskab. Forfatteren er «livsvarig» formann i dette selskap, slik at støtten er forståelig, og medlemmene har da også fått boken i gave. Tidsskriftets forhold til utgivelsen er litt mer uklar. Tidsskriftet har vel en slags copyright, men har tydeligvis ikke bidratt til prosjektet. En konflikt er også antydet i og med at forfatterens avtale med Tidsskiftet plutselig ble oppsagt, og forfatterens forslag til forsider for ett år ikke ble brukt og materialet ikke returnert.

Denne anmelder har hatt betydelig glede av gjensynet med både bilder og Øivind Larsens kommentarer. Jeg er sikker på at mange kolleger vil ha samme opplevelse og anbefaler boken varmt. Lesingen vil gi både litterær glede og nye kunnskaper. Så får vi heller tilgi historieprofessoren at han feilaktig(?) henlegger Vesalius og Harveys aktiviteter til Bologna og ikke til Padova.

\section{Ragnar Stien}

Oslo 